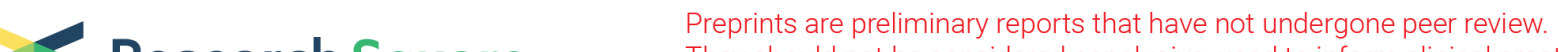 Research Square They should not be considered conclusive, used to inform clinical practice, or referenced by the media as validated information.
}

\section{CmPMRI and CmPMrs Were Responsible for Resistance to Powdery Mildew Caused by Podosphaera Xanthii Race 1 in Melon}

Haonan Cui ( $\nabla$ cuihaonan2008@163.com )

Northeast Agricultural University https://orcid.org/0000-0002-7151-7168

\section{Chao Fan}

Heilongjiang Academy of Agricultural Science

Zhuo Ding

Northeast Agricultural University

Xuezheng Wang

Northeast Agricultural University

\section{Lili Tang}

Heilongjiang Academy of Agricultural Sciences

\section{Yingdong Bi}

Heilongjiang Academy of Agricultural Sciences

Feishi Luan

Northeast Agricultural University

\section{Peng Gao}

Northeast Agricultural University

\section{Research Article}

Keywords: Melon, powdery mildew, finally mapping, ANK, MLO

Posted Date: September 21st, 2021

DOI: https://doi.org/10.21203/rs.3.rs-223835/v1

License: (1) (1) This work is licensed under a Creative Commons Attribution 4.0 International License. Read Full License 


\section{Abstract}

Cucumis melo L. is an economically important crop, the production of which is threatened by the prevalence of melon powdery mildew (PM) infections. We herein utilized the MR-1 ( $\mathrm{P}_{1}$; resistant to PM) and M4-7 ( $\mathrm{P}_{2}$; susceptible to PM) accessions to assess the heritability of PM (race 1) resistance in these melon plants. PM resistance in MR-1 leaves was linked to a dominant gene (CmPMRI), whereas stem resistance was under the control of a recessive gene (CmPMrs), with the dominant gene having an epistatic effect on the recessive gene. The $C m P M R /$ gene was mapped to a $50 \mathrm{~Kb}$ interval on chromosome 12, while CmPMrs was mapped to an $89 \mathrm{~Kb}$ interval on chromosome 10. The CmPMRI candidate gene MELO3C002441 and the CMPMrs candidate gene MELO3C012438 were identified through sequence alignment, functional annotation, and expression pattern analyses of all genes within these respective intervals. MELO3C002441 and MELO3C012438 were both localized to the cellular membrane and were contained conserved NPR gene-like and MLO domains, respectively, which were linked to PM resistance. In summary, we identified patterns of PM resistance in the disease-resistant MR1 melon cultivar, and conducted finally-mapping to identify two putative genes linked to resistance. Our results offer new genetic resources and markers guide the future molecular marker-assisted breeding of PM-resistant melon.

\section{Key Message}

Two genes for resistance to Podosphaera xanthii race 1 in melon were identified on chromosomes 10 and 12 of the Cucumis melo cultivar MR-1

\section{Introduction}

Powdery mildew (PM) is a disease that can adversely affect the production of economically important cucurbit crops including melons, cucumbers, and pumpkins. PM can develop in greenhouses and open fields, incurring substantial crop losses. In 2018, 358,900 hectares of melon crops were planted in China, accounting for $34.28 \%$ of the overall global melon crop area, with a total output of $12,788,200$ tonnes, accounting for $46.76 \%$ of the overall global output, making China the leading global melon producer (FAO, 2018). Pathogens responsible for PM development include Ascomycotina fungal species, with Golovinomyces cichoracearum (formerly Erysiphe cichoracearum) and Podosphaera xanthii (formerly Sphaerotheca fuliginea) being the two best studied of these species (Kř́stková et al. 2009). P. xanthii is the only species that has been shown to cause PM in Israel, Turkey, Italy, Spain, Australia, South Africa, and Japan (Kř́stková et al. 2009), whereas both of these fungi have been identified as pathogenic agents in France, the USA, and the Czech Republic, although $P$. xanthii remains dominant in these regions (McCreight et al. 1987; Krístková et al. 2007). G. cichoracerum has also been detected as a cause of this disease in the Netherlands, the former Soviet Union, Germany, and the United Kingdom (Braun 1995). In China, $P$. xanthii races 1 and $2 F$ are the dominant causes of $P M$, with other races being reported relatively infrequently. 
In melon, resistant genes Pm-1, Pm-2, Pm-3, Pm-4, Pm-5, Pm V.1, Pm XII. 1, Pm-F, Pm-G, Pm-X, Pm-w, Pm-B, Pm-Edisto47-1, Pm-Edisto47-2 and BPm12.1 have all been reported to promote resistance to infection with $P$. xanthii physiological race 1 . Jagger et al. (1938) reported a dominant single gene associated with $P$. xanthii race 1 resistance in melons, and called this gene $P m-1$ (Teixeira et al. 2008). Harwood and Markarian (1968a) also identified $P m-1$ and detected another resistance gene ( $P m-2)$ that together promoted resistance to $P$. xanthii infection. Harwood and Markarian (1968b) further identified the Pm-3, $P m-4$, and Pm-5 resistance genes in PI 124112 (Harwood and Markarian 1968b), the latter two of which were defined as PmV.1 and PmXII. 1 by Perchepied et al (2005). These genes may be identical to Pm-F and $P m-G$, which were previously identified in a study conducted by Epinat et al. (1992). The dominant $P m-x$ gene was initially reported in PI 414723 by Pitrat et al. (1991), who also reported the single dominant $P m-w$ gene in the disease-resistant WMR29 melon cultivar, with the location of this gene being consistent with the location of $P M-B$ reported by Epinat et al. (1992). Ning et al. (2014) reported the disease resistance loci Pm-Edisto47-1 and Pm-Edisto47-2 on melon chromosomes 2 and 5, respectively. $\mathrm{Li}$ et al. (2017) identified a dominant disease resistance gene (BPm12.1) in the MR-1 melon strain which they localized to melon chromosome 12 (Table S1).

There have been relatively few studies of other physiological races of powdery mildew. The resistance gene Pm- 6 was identified as being related to P.xanthii race 2 resistance in PI 124112 (Kenigsbuch, 1989). In 2010, one study found that disease resistance in the PI 134198 melon variety was controlled by a single dominant gene $(\mathrm{Pm}-8)$, but the pathogenic physiological races included in that study were distinct from the current common races. McCreight and Coffey (2011) also reported a gene associated with race $S$ resistance in 2011 , but the genetic relationships among these genes remain unclear (Table S1).

In addition, it is likely that undiscovered disease resistance genes exist in other melon varieties or in wild and semi-wild resources, and the identification of these genes represents an important future direction for the breeding of resistant lines (Cui et al. 2018). The MLO gene is also a recessive resistance-related gene, and mutant MLO genes are associated with PM resistance in plants. lovieno et al. (2015) systematically classified and predicted MLO genes in melon, cucumber, and zucchini plants. A series of studies performed by Cheng Hong et al. $(2012,2013,2015)$ also found that mutant MLO genes in melon and wild melon plants play broad-spectrum roles in the context of PM resistance.

Herein, we used $F_{1}, F_{2}, B C_{1} P_{1}$, and $B C_{1} P_{2}$ plants prepared using the disease-resistant MR-1 and diseasesensitive M4-7 parental melon lines to evaluate patterns of disease resistance. Preliminary PM resistancerelated gene mapping was conducted via QTL-seq analyses the $F_{2}$ population, while $F_{2}$ and $F_{3}$ populations were utilized to validate the results of such preliminary mapping. Finally mapping was performed using molecular markers in $\mathrm{F}_{2}$ and $\mathrm{F}_{3}$ populations, enabling us to identify candidate resistance genes within the mapped resistance-related intervals based upon the results of gene sequence alignment, functional annotation, and expression pattern analyses following PM infection. The functional roles of two identified candidate resistance genes were predicted, and subcellular localization analyses were conducted, providing a theoretical foundation for future studies of the functional roles of these and other genes associated with melon PM resistance. Our study also highlights valuable molecular markers and 
safeguards that can aid in the molecular marker-assisted selective breeding of melon plants with the goal of developing PM-resistant cultivars.

\section{Materials And Methods Plant materials}

The PM-resistant MR-1 melon line was selected as the female parent, while the susceptible M4-7 line was chosen as the male parent in the following breeding scheme: $F_{1}(M R-1 \times M 4-7), B C_{1} P_{1}\left(F_{1} \times M R-1\right), B_{1} P_{2}\left(F_{1}\right.$ $\times M 4-7), F_{2}\left(F_{1} \times F_{1}\right)$. In total, 13 differential lines (Iran H, TopMark, Védrantais, PMR 45, PMR 5, WMR 29, Edisto 47, PI 414723, MR-1, PI 124111, PI 124112, PMR 6, and Nantais Oblong) were utilized to assess $P$. xanthii race 1 susceptibility (Bardin et al. 1999; Hosoya et al. 1999, 2000; McCreight 2006).

In the summer of 2017, these materials were grown in a greenhouse at the Northeast Agricultural University Facility Horticulture Engineering Center $\left(44^{\circ} 04^{\prime} \mathrm{N}, \mathrm{E} 125^{\circ} 42^{\prime}\right)$. A total of 10 plants were planted for each of the 13 different host lines, while 30 plants each were grown for the $P_{1}(M R-1), P_{2}\left(M_{4}-7\right), F_{1}$, $\mathrm{BC}_{1} \mathrm{P}_{1}$, and $\mathrm{BC}_{1} \mathrm{P}_{2}$ lines. In addition, 396 total $\mathrm{F}_{2}$ plants were grown to analyze patterns of genetic inheritance and to localize the resistance loci. In 2018, $1022 F_{2}$ and $726 F_{3}$ individuals were planted used for finally-mapping.

\section{Microscopic Analyses Of Powdery Mildew Fungus}

Melon leaves infected with powdery mildew were collected and treated with a decolorizing solution $\left(0.15 \%\right.$ trichloroethanol-trichloromethane) at $60^{\circ} \mathrm{C}$ for $1-2 \mathrm{~h}$ at a constant temperature until the leaves were completely decolorized. Leaves were then treated with a staining solution (0 15\% trichloroacetic acid $+6 \%$ Cumas Brilliant Blue R-250 in 99\% methanol) for 3-5 min, rinsed with sterile water, and observed for powdery mildew hyphae, haustorium, and conidiophore morphology using an ordinary light microscope.

\section{Pm Resistance Phenotyping}

PM fungi isolated from melon plants were collected in distilled water mixed with 1-2 drops of Tween, after which conidia suspensions were assessed via microscopy. Solutions were diluted until there were 20-30 conidia per microscopic field of view, at which time spore suspensions were sprayed over the entirety of melon plants ( $\mathrm{Ma}$ et al. 2011). The leaves of 13 different melon lines were inoculated in this manner and the causative pathogen was identified as $P$. xanthii race 1 based upon the differential reactions of these 13 lines to the pathogen as determined based on the criteria previously detailed by McCreight (2006). In this study, plants without white spots were defined as resistant and those with white spots were defined as susceptible. 
A total of 15 MR-1 and 15 M4-7 plants were then taken and inoculated with the above $P$. xanthii race 1 preparation under close management conditions, whereas the remaining 15 plants per group were inoculated in the same manner under field management conditions. Following inoculation, leaves and stems from these plants were collected at 24,48 , and $72 \mathrm{~h}$ post-inoculation, snap-frozen with liquid nitrogen, and stored at $-80^{\circ} \mathrm{C}$. Following $\mathrm{F}_{3}$ plant inoculation, $\mathrm{F}_{3}$ stem resistance was assessed, with $\mathrm{F}_{3}$ individuals conforming to a 1:3 ratio being retained. Together with genotyping results, these $F_{3}$ plants were derived from the self-pollination of a single $F_{2}$ individual with the RIRI genotype and used as an $F_{3}$ population for CmPMrs finally mapping.

\section{Dna Extraction And Pooling}

Genomic DNA was extracted from leaves via a modified CTAB method (Allen et al. 2006). Plants with disease-free stems and leaves were recorded as $L_{R} S_{R}$ (L: leaf, $S$ : stem, $R_{R}$ : resistance, s: susceptibility), whereas plants with visible lesions on stems but not leaves were recorded as $L_{R} S_{S}$, and those with lesions on both tissue types were recorded as $L_{S} S_{S}$. Following inoculation, these three susceptibility phenotypes were selected from among $F_{2}$ plants, and 20 plants per phenotype were combined to yield three pooled DNA samples.

\section{Bulked Segregant Analysis}

An Illumina HiSeq 2500 instrument was used to sequence DNA samples from two parents and three gene pools (BGI Bio). The genome-wide resequencing data from the two parents were aligned with the DHL92 v3.5.1 reference genome (Garcia-Mas et al. 2012) using a Burrows-Wheeler Aligner approach to detect single nucleotide polymorphisms (SNP), which were identified using samtools 1.0 ( $L i$ et al. 2009) from a BAM format file and annotated using the SnpEff tool (Cingolani et al. 2012). We excluded SNP positions with a SNP-index value of $<0.3$ and a read depth $<6$ from the two sequences. A sliding window analysis was applied to SNP-index plots, with a $2 \mathrm{Mb}$ window size and $10 \mathrm{~Kb}$ increments. We calculated the average SNP-index values for the SNPs located within this window and used these for the sliding window plots (Takagi et al. 2013).

SNP-index values were estimated as follows (Zheng et al. 2018):

(1) SNP-index ( $x x)=R x x /(S x x+R x x)$

(2) SNP-index (yy) = Syy / (Ryy + Syy)

(3) $\Delta($ SNP-index $)=$ SNP-index (xx) - SNP-index (yy)

Where R corresponds to MR-1 and S corresponds to M4-7. $x x$ and yy are the reads from different gene pools. Rxx indicates the depth of $x x$ derived from R, Syy indicates the depth of yy derived from $S$, and Sxx 
and Ryy indicate similarities.

Only regions with a fitting value greater than the $95 \%$ confidence interval threshold were considered for this analysis.

\section{CAPS marker development and secondary mapping by QTL analysis based on BSA results}

SNPs that differed between parental lines were identified via sequence comparisons, with the SNP2CAPS software being used to select SNPs on Alul, Bcll, Dral, EcoRl, BsaHI, HindIII, Mboll, Pstl, BamHI, Mlul, Scal, Pvul, Xhol, Taql, Kpnl, and Mspl. Primers specific for 500 bp regions before and after these SNPs (1000 bp total) were then designed using Primer Premier 6.0. Two parents and $F_{1}$ plants were used to screen for polymorphisms for use as CAPS markers for the genotyping of $F_{2}$ and $F_{3}$ populations. Genetic linkage map construction was performed using the IciMapping V3.3 software (Institute of Crop Science, Chinese Academy of Agricultural Sciences, Beijing, China) (Meng et al. 2015), and all the markers were grouped at a minimum logarithm of odds (LOD) score of 6.0. The QTL analysis was also performed using IciMapping V3.3 (Meng et al. 2015). Composite interval mapping (CIM) was used to search QTLs for PM resistance on one chromosome, with QTLs with an LOD score $\geq 5.0$ being considered for detection.

\section{Qrt-pcr}

A Trizol approach was used to extract RNA from samples (Rio et al. 2010), after which cDNA was prepared using a Toyobo reverse transcription kit. All real-time qRT-PCR reactions were conducted using the Tiangen Biochemical Technology RealMaster Mix SYBR Green kit. Primers were synthesized by Sangon Biotech, and were designed with Primer Premier 5.0. The relative expression of all genes within the finally location was assessed, with vertical coordinates corresponding to relative expression and horizontal coordinates corresponding to the time of inoculation $(0,2$, or 4 days post-inoculation). The $2^{-\triangle \Delta C T}$ approach was used to assess relative gene expression (Livak and Schmittgen, 2001), MELO3C023264 (Actin) was utilized as a housekeeping gene. Differences in relative expression were analyzed using SPSS v23.0.

\section{Candidate Gene Cloning And Subcellular Localization}

To clone candidate genes, DNA recovery kits (Takara) were used to retrieve fragments of the appropriate size for cloning using the pEASY-T1 Cloning Kit (TransGen Biotech). The ligated product was then transformed into competent $E$. coli DH5a cells (TransGen Biotech), with an M13 primer being used for PCR analyses of bacterial solutions. Next, $0.5 \mathrm{~mL}$ of this bacterial solution was aspirated, mixed with 0.5 $\mathrm{mL}$ of $30 \%$ glycerol, and stored at $-80^{\circ} \mathrm{C}$. Bacterial sequencing was performed by Sangon Biotech.

MELO3C002441 and MELO3C012438 ORF sequences from which the stop codon had been removed were fused to a GFP sequence to prepare an expression vector. Next, a tobacco leaf injection method was used 
to assess the localization of these constructs within cells. At 3 days post-inoculation, tobacco leaves were taken from the injection site to prepare slides which were evaluated via confocal microscopy, with Agrobacterium transformed with an empty vector serving as a control. Chloroplast autofluorescence at a $640 \mathrm{~nm}$ excitation wavelength was assessed, while GFP signal was assessed at an excitation wavelength of $488 \mathrm{~nm}$.

\section{Phylogenetic Analysis Of Candidate Genes}

Candidate genes were subjected to BLAST matching against the NCBI database (https://www.ncbi.nlm.nih.gov/) to identify candidate gene homologs and their amino acid sequences in other plants, and phylogenetic analysis was carried out using the MEGA-X software.

\section{Results}

\section{Powdery mildew isolate classification}

Leaves from PM-infected melon plants were stained using Coomassie Brilliant Blue, and the conidia therein appeared ovoid in shape. Fibrous bodies were clearly visible in the cytoplasm with a length of 57$76 \mu \mathrm{m}$ and a width of 38-44 $\mu \mathrm{m}$, consistent with the characteristics of $P$. xanthii (Fig. 1). Following inoculation, the susceptibility of 13 different host lines to this isolate was evaluated (Table 1), and resistance responses were consistent with the identity of this isolate as $P$. xanthii race 1 , with no change in the dominant strain having occurred over the course of the year. 
Table 1

The PM infection outcomes for 13 differential hosts

\begin{tabular}{|lll|}
\hline Differential hosts & Resistance evaluation in 2017 & Resistance evaluation in 2018 \\
\hline IranH & S & S \\
\hline Top Mark & S & S \\
\hline Vedrantais & S & S \\
\hline PMR 45 & S & S \\
\hline PMR 5 & R & R \\
\hline WMR 29 & R & R \\
\hline Edisto 47 & R & R \\
\hline PI 414723 & R & R \\
\hline MR-1 & R & R \\
\hline PI 124111 & R & R \\
\hline PI 124112 & R & R \\
\hline PMR 6 & R & R \\
\hline Nantais Oblong & S & S \\
\hline Note: R: resistant, S: susceptible & \\
\hline
\end{tabular}

\section{Genetic Analyses Of Pm-resistant And Pm-susceptible Melon Lines}

As shown in Table 2, the stems and leaves of the female parental MR-1 line were disease resistant, whereas those of the male parental M4-7 were susceptible to PM. The leaves of $F_{1}$ plants were resistant to disease, whereas the stems of these plants were susceptible. $F_{2}$ plant isolation yielded plants conforming to three phenotypes: leaf and stem resistant $\left(L_{R} S_{R}\right)$, leaf resistant stem susceptible $\left(L_{R} S_{S}\right)$, and leaf and stem susceptible $\left(L_{S} S_{S}\right)$. $B C_{1} P_{1}$ plants conformed to the $L_{R} S_{R}$ and $L_{R} S_{S}$ phenotypes, whereas $B C_{1} P_{2}$ plants conformed to the $L_{R} S_{S}$ and $L_{S} S_{S}$ phenotypes. 
Table 2

Disease responses for $\mathrm{P}_{1}, \mathrm{P}_{2}, \mathrm{~F}_{1}, \mathrm{~F}_{2}, \mathrm{BC}_{1} \mathrm{P}_{1}$, and $\mathrm{BC}_{1} \mathrm{P}_{2}$ populations following artificial inoculation with $P$. xanthii race 1 , with Chi-squared verification of the $F_{2}$, $B C_{1} P_{2}$ segregation ratios between resistant $(R)$ and susceptible $(S)$ individuals.

\begin{tabular}{|c|c|c|c|c|c|c|c|}
\hline Year & Generation & $\mathrm{L}_{\mathrm{R}} \mathrm{S}_{\mathrm{R}}$ & $L_{R} S_{S}$ & $\mathrm{~L}_{s} \mathrm{~S}_{\mathrm{S}}$ & Excepted Ratio & $x^{2}$ & P Value \\
\hline \multirow[t]{6}{*}{2017} & $\mathrm{P}_{1}$ & 30 & - & - & - & - & - \\
\hline & $\mathrm{P}_{2}$ & - & - & 30 & - & - & - \\
\hline & $\mathrm{F}_{1}$ & & 30 & - & - & - & - \\
\hline & $\mathrm{F}_{2}$ & 224 & 73 & 99 & $9: 3: 4$ & 0.03 & 0.98 \\
\hline & $\mathrm{BC}_{1} \mathrm{P}_{1}$ & 14 & 16 & - & $1: 1$ & 0.13 & 0.72 \\
\hline & $\mathrm{BC}_{1} \mathrm{P}_{2}$ & - & 13 & 17 & $1: 1$ & 0.53 & 0.47 \\
\hline \multirow[t]{4}{*}{2018} & $\mathrm{P}_{1}$ & 30 & - & - & - & - & - \\
\hline & $\mathrm{P}_{2}$ & - & - & 30 & - & - & - \\
\hline & $\mathrm{F}_{1}$ & - & 30 & - & - & - & - \\
\hline & $\mathrm{F}_{2}$ & 577 & 189 & 256 & $9: 3: 4$ & 0.04 & 0.97 \\
\hline
\end{tabular}

A dominant gene (CmPMRI) was found to control leaf resistance to powdery mildew, while a recessive gene (CmPMrs) was found to control resistance to powdery mildew on stems and vines. Analyses of inheritance patterns indicated that $C m P M R /$ had a recessive epistasis effect on CmPMrs. In the $\mathrm{F}_{2}$ population, the ratios of $L_{R} S_{R}: L_{R} S_{S}: L_{S} S_{S}$ were consistent with a 9:3:4 ratio, as determined via $\chi 2$ test. In the $B C_{1} P_{1}$ population, the $L_{R} S_{S}: L_{R} S_{R}$ ratio was consistent with a 1:1 ratio as determined by $\chi 2$ test. In the $B C_{1} P_{2}$ population, the $L_{R} S_{S}: L_{S} S_{S}$ ratio was consistent with a $1: 1$ ratio as determined by $\chi 2$ test.

\section{BSA and QTL analysis of the dominant resistance gene CmPMRI}

MR-1 sequencing produced 134,014,482 reads, of which $95.0 \%$ could be mapped to the reference genome, M4-7 sequencing produced 122,001,928 reads, of which $93.8 \%$ could be mapped to the reference genome, and a total of 2,761,801 SNPs were identified between MR-1 and M4-7. In addition, $39,710,623$ reads were sequenced in $L_{R} S_{R}$ pool, with a reference genome mapped rate of $93.17 \%$, $43,930,213$ reads were sequenced in $L_{S} S_{S}$ pool, with a reference genome mapped rate of $91.10 \%$, and $45,151,799$ reads were sequenced in $L_{R} S_{S}$ pool, with a reference genome mapped rate of $92.82 \%$.

SNP index values were calculated according to sequencing data from three gene pools with corresponding $95 \%$ confidence intervals. The $L_{R} S_{R}$ and $L_{S} S_{S}$ pool results revealed the candidate gene to be localized within the 21.7-23.3Mb interval on chromosome 12 (Fig. 2a). When the $L_{R} S_{S}$-pool and $L_{S} S_{S}$ - 
pool were calculated, the location was roughly the same as that calculated using the $L_{R} S_{R}$-pool and $L_{S} S_{S^{-}}$ pool, extending from 21.6 to $23.2 \mathrm{Mb}$ (Fig. 2b). These results indicated that the dominant CmPMR/gene, which controls disease resistance in leaves and stems, is located in the 21.6-23.3 Mb interval on chromosome 12 (Fig. 2c). Based on the preliminary BSA localization results, 13 polymorphic markers (68.42\% polymorphic) were selected within this initial CmPMR/ location (Table S2). In total, $93 \mathrm{~F}_{2}$ individuals were selected to construct a validation population, and 13 pairs of primers (PM12-V1 to $P M 12-V 13)$ were used for $F_{2}$ genotyping. Phenotypic leaf disease resistance data in the $F_{2}$ population was then used to localize the main effect locus associated with PM resistance in melon leaves to between PM12-V4 and PM12-V10 (21.59-23.30 Mb) on chromosome 12, with an LOD of 47.2 (Fig. 2d).

\section{BSA and QTL analyses of the recessive resistance gene CmPMrs}

Using a marker tightly linked to the CmPMR/ gene (PM12R-6), we screened 726 plants with the same genotype and leaf phenotype as the disease-resistant parental MR- 1 line. In the $F_{2}$ population, the stem disease-resistant phenotype separated at a 1:3 ratio, thus eliminating the effect of CmPMR/ on CmPMrs (Table S3). Stem resistance was therefore considered to be a trait controlled by a recessive allele. The $L_{R} S_{R}$-pool and $L_{R} S_{S}$-pool results revealed the candidate gene to be located within the $0-2.03 \mathrm{Mb}$ interval of chromosome 10 (Fig. 3a, b). Based on preliminary BSA localization results, 12 polymorphic markers were screened in the initial CmPMrs location (63.16\% polymorphic) (Table S4), and $93 \mathrm{~F}_{3}$ individuals were selected to construct a validation population, after which 12 primer pairs (PM10-V1 - PM12-V12) were used for $F_{3}$ genotyping. With respect to stem resistance phenotype data in the $F_{3}$ population, the main effect loci related to PM resistance was localized between PM10-V1 and PM10-V8 (0-2.04 Mb) on chromosome 10, and the LOD was 31.6 (Fig. 3c).

\section{Finally mapping of the dominant resistance gene CMPMRI and recessive resistance gene CmPMrs}

In this study, $1022 \mathrm{~F}_{2}$ plants were genotyped with markers $P M 12 R-1$ to $P M 12 R-12$ (Table S2) and 20 recombinant plants were identified, further identifying the location of the dominant resistance gene CmPMRI. The CmPMR/ was found to exist between markers PM12R-5 and PM12R-7 (22.78-22.91 Mb). Six new CAPS markers (Table S2) were developed and used to genotype the 5 recombinants $\left(\mathrm{F}_{2}-395, \mathrm{~F}_{2}\right.$ $89, \mathrm{~F}_{2}-288, \mathrm{~F}_{2}-715$, and $\left.\mathrm{F}_{2}-1002\right)$. Gene recombination occurred between markers $P M 12 R-A D 1, P M 12 R-$ $A D 4$ and $P M 12 R-A D 6$, enabling us to determine that the $R 1$ gene was localized between the PM12R-AD1 and PM12R-AD4 markers (Chr12: 22786222-22836405, about $50 \mathrm{~Kb}$ ) (Fig. 4a, Table S5). No recombination was observed for the $P M 12 R-A D 2$ and $P M 12 R-A D 3$ markers, suggesting that this segment is the smallest segment localized to the $R 1$ gene interval in the $\mathrm{F}_{2}$ population.

Genotyping of $726 \mathrm{~F}_{3}$ plants using markers $P M 10 R-1$ to $P M 10 R-12$ (Table S4) identified 18 recombinant plants, leading to the location of the recessive resistance gene CmPMrs. The CmPMrs location was thus determined to be between markers PM1OR-4 and PM1OR-5 (0.47-0.59 Mb). Four new CAPS markers (Table S4) were developed and used to genotype the three recombinants $\left(F_{3}-591, F_{3}-116\right.$, and $\left.F_{3}-106\right)$. 
Recombination occurred only for labeled $P M 10 R-A D 4$, with no recombination between labeled $P M 10 R$ $A D 1$ and PM10R-AD4. This led us to refine the CmPMrs location between markers PM1OR-AD1 and PM1OR-AD4 (Chr10:466642-552080, about $86 \mathrm{~Kb}$ ) (Fig. 4b, Table S6), suggesting that this segment is the smallest that can be used to locate the CmPMrs gene interval.

\section{Candidate Genes Functional Annotation And Sequence Alignment}

When the CmPMR/ finally-mapping interval was aligned to the DHL92 melon reference genome, we identified nine protein-coding genes (MELO3C002441-MELO3C002449) within this interval, of which six harbored nonsynonymous mutations between the two parental lines. Functional annotation of these genes revealed MELO3C002445 to be unclassified, MELO3C002441 and MELO3C002443 to be involved in signal transduction, MELO3C002442 and MELO3C002444 to be involved in lipid and protein metabolism, MELO3C002446 to play roles in unclear biological processes, MELO3C002447 to be involved in redox reactions, MELO3C002448 to be involved in the control of phosphate hydrolase activity, and MELO3C002449 to be involved in glycolytic enzyme activity (Table 3).

Table 3

List of the predicted candidate genes in the CMPMR/ candidate region

\begin{tabular}{|c|c|c|}
\hline Gene ID & The number of nsSNPs & Description of gene function \\
\hline MELO3C002441 & 1 & Ankyrin repeat family protein \\
\hline MELO3C002442 & 2 & Aspartic proteinase \\
\hline MELO3C002443 & 1 & F-box plant-like protein, putative \\
\hline MELO3C002444 & 0 & Aminomethyltransferase \\
\hline MELO3C002445 & 2 & unkown protein \\
\hline MELO3C002446 & 2 & Glycine-Rich cell wall structural protein \\
\hline MELO3C002447 & 0 & L-ascorbate oxidase \\
\hline MELO3C002448 & 0 & phosphatase family protein \\
\hline MELO3C002449 & 1 & Glucan endo-13-beta-glucosidases \\
\hline Total & 9 & \\
\hline
\end{tabular}

This same analytical approach led to the identification of 11 candidate genes within the CmPMrs finallymapping interval, of which seven harbored nonsynonymous mutations between the two parental lines (MELO3C012428-MELO3C012438). Functional annotation of these genes revealed them to be primarily associated with plant physiological and biochemical responses (Table 4), including substance metabolism (MELO3C012428, MELO3C012430, MELO3C0124233, MELO3C012434, MELO3C012435), substance transport (MELO3C012429, MELO3C012436), redox reactions (MELO3C012431), pollen 
budding and pollen tube elongation (MELO3C012432), ubiquitination (MELO3C012437), and PM resistance (MELO3C012438).

Table 4

List of the predicted candidate genes in the CmPMrs candidate region

\begin{tabular}{|c|c|c|}
\hline Gene ID & $\begin{array}{l}\text { The number of } \\
\text { nsSNPs }\end{array}$ & Description of gene function \\
\hline \multirow[t]{2}{*}{ MELO3C012428 } & 0 & mRNA decapping protein 2 \\
\hline & & nuclear-transcribed mRNA \\
\hline MELO3C012429 & 0 & Aquaporin 2 \\
\hline MELO3C012430 & 1 & Alpha/beta hydrolase family protein \\
\hline MELO3C012431 & 9 & Thioredoxin-like protein \\
\hline MELO3C012432 & 0 & $\begin{array}{l}\text { Pollen-specific leucine-rich repeat extensin-like protein } \\
1\end{array}$ \\
\hline MELO3C012433 & 2 & Patatin \\
\hline MELO3C012434 & 0 & Anthranilate synthase component I \\
\hline MELO3C012435 & 5 & phosphatase family protein \\
\hline MELO3C012436 & 1 & Probable protein kinase \\
\hline MELO3C012437 & 1 & Ubiquitin-conjugating enzyme, E2 \\
\hline MELO3C012438 & 1 & MLO-like protein \\
\hline Total & 20 & \\
\hline
\end{tabular}

\section{Assessment Of Candidate Gene Expression Patterns}

A qRT-PCR analysis of genes expressed within the CmPMR/locus revealed that MELO3C002441, MELO3C002444, and MELO3C002448 were significantly upregulated in disease-resistant MR-1 leaves following inoculation, whereas MELO3C002446, MELO3C002447, and MELO3C002449 were downregulated, and the expression of the other three genes was unaffected. The expression of MELO3C002441 was also significantly elevated in stem tissues, but was expressed at a lower level therein relative to leaves, consistent with the CMPMR/gene expression pattern (Fig. 5a). Following the inoculation of M4-7 plant materials, relative MELO3C002441 expression was significantly reduced in leaves, whereas it was expressed at an at least three-fold higher level in MR-1 leaves relative to M4-7 leaves, suggesting that this gene is expressed at substantially different levels in PM-resistant and PMsusceptible plants (Fig. $5 b$ ). This gene encodes an anchor protein-containing repeat sequence harboring a nonsynonymous SNP that alters the identity of the amino acid in position 587 from a phenylalanine (Phe) in MR-1 plants to a cysteine (Cys) in M4-7 plants. Based on these findings, MELO3C002441 was 
identified as a CmPMR/ candidate gene. For other details regarding expression levels of these genes, see Figures S1-S2.

A qRT-PCR analysis of genes in the CmPMrs locus revealed MELO3C012429 and MELO3C012438 to be significantly upregulated in stem tissues after susceptible M4-7 plant material inoculation, whereas MELO3C012430, MELO3C012432, MELO3C012433, and MELO3C012436 were significantly downregulated, and the expression of the other five genes was unaffected. Of the two upregulated genes, MELO3C012429 was significantly upregulated in stem tissues but did not exhibit altered expression levels in leaves. MELO3C012438 expression rose significantly in the stem on day 4, with a $>2$-fold increase in relative expression, whereas its expression levels in leaves were reduced such that this gene was expressed at significantly lower levels in leaf tissues relative to stem tissues at specific time points following inoculation (Fig. 5c). MELO3C012429 was expressed at significantly higher levels in the leaves of disease-resistant MR-1 plants relative to stems, and such expression was not altered following inoculation. In contrast, MELO3C012438 expression rose significantly in both leaf and stem tissues following inoculation, with significantly higher expression in stems relative to leaves at specific time points (Fig. 5d). MELO3C012438 encodes an MLO-like protein harboring a nonsynonymous SNP that alters the identity of the amino acid in position $191 \mathrm{from}$ an isoleucine (Ile) in MR-1 plants to a threonine (Thr) in M4-7 plants. Based on these results, we identified MELO3C012438 as a candidate for the CmPMrs gene. For details regarding the expression levels of other genes, see Figure S3-S4.

\section{Candidate Gene Subcellular Localization}

We next evaluated the localization of MELO3C002441 and MELO3C012438 within cells (Fig. 6), with chloroplast autofluorescent signal being used to guide localization efforts. This analysis revealed that the MELO3C002441-GFP fusion protein primarily localized to the cell membrane (Fig. 6a-d). MELO3C012438 exhibited localization largely identical to that of MELO3C002441, localizing to the cell membrane in a manner consistent with transmembrane domain predictions (Fig. 6e-h). The subcellular localization of these proteins may be linked to their functional role in the context of PM resistance, as they control melon epidermal cell resistance to PM infection.

\section{Phylogenetic Analysis Of Candidate Genes}

Phylogenetic analyses indicated that the MELO3C002441 protein clustered with soybean GmNPR4 and GmNRP4-like proteins, and was genetically distant from NPR proteins in other crops, suggesting that this gene is an anchor protein repeat sequence-containing gene that is functionally similar to the soybean NPR4 gene (Ankyrin repeat protein). Conservative structural domain analysis revealed that this gene harbored an N-terminal ANK-2 type anchor protein repeat sequence and a C-terminal PPG structural domain (Figure S5a, S6a). 
The MELO3C012438 protein clustered with the cucumber CsaV35G036400 and watermelon Cla020573 proteins, which in turn clustered with the Arabidopsis AtMLO2, AtMLO6, and AtML012 proteins. These three proteins were genetically distant from the other MLO proteins, suggesting that this gene is an MLO family gene (Mildew Resistance Locus 0) with functional similarity to Cucumber CsMLO8 and Arabidopsis AtMLO2, AtMLO6, and AtML012. Conserved structural domain analysis indicated that the gene encodes a conserved MLO structural domain (Figure S5b, S6b).

\section{Discussion}

In research on plant disease resistance, many $R$ genes have now been cloned, and in 2018 , researchers analysed $128 R$ genes and delineated nine different types based on their disease resistance mechanisms (Kourelis and van der Hoorn. 2018). In the study of plant resistance to powdery mildew, the clearer mechanisms of resistance are RPW8.1 and RPW8.2 found in Arabidopsis, which recognize the invasion of plant cells by haustorium and enhance the accumulation of hydrogen peroxide in the haustorium complex and the encapsulation of callus through the cytoskeletal function of actin towards the vicinity of the sucker membrane in elongation, thus enhancing (Orgil et al. 2007, Kim et al. 2014). In addition, in barley and Arabidopsis, the $M L O$ gene was found to have a transcriptional regulatory function in the antifungal immune system, suggesting that this gene has a negative regulatory role in the plant defence response and suppresses the plant systemic immune response (Humphry et al. 2006, Humphry et al. 2010).

Breeding melon plants that are resistant to local PM strains is a key agricultural priority. Reports of PMresistant melon germplasm resources were published as early as 1937, with over 30 types of PM-resistant melon materials having been described to date (de Oliveira Rabelo et al. 2017), encompassing over 20 resistance-associated genes including $P m-1, P m-2, P m-3, P m-4, P m-5, P m-6, P m-R, P m-W, P m-X, P m-Y$, PmV.1, PmXII.1, Pm-pxA, Pm-pxB, Pm-An, pm-S, Pm-2F, Pm-x1, Pm-x3, Pm-x5, BPm12.1, Pm2.1, and pm12.1 (Cohen et al. 1990; Pitrat 1991; Périn et al. 2002; Perchepied et al. 2005; Fukino et al. 2008; Dogimont 2011; McCreight and Coffet 2011; Wang et al. 2011; Yuste-Lisbona et al. 2011; Zhang et al. 2012; Fazza et al. 2013; Li et al. 2017; Cui et al. 2020). This study is the first to have conducted the finallymapping of two melon genes associated with the resistance to $P$. xanthii race 1 and to have identified proposed candidate genes associated with these phenotypes.

Herein, we identified MELO3C002441 and MELO3C012438 as candidate genes for the CMPMR/ and CmPMrs associated with resistance to PM in the leave and stem of melon, respectively. The MELO3C002441 gene was identified as an ANK protein family member that may be involved in systemic resistance to PM, while MELO3C012438 was found to encode a conserved MLO domain, and may be a recessive gene linked to $\mathrm{PM}$ resistance.

A non-synonymous SNP in the CMPMR/ candidate gene MELO3C002441 may be linked to the functional variability associated with this gene in melon accessions. Disease resistance-related genes typically exhibit altered expression in response to disease. Román et al. (2019) leveraged this fact to identify 
CmARP4 as one such candidate disease resistance gene. We similarly explored gene expression patterns and found MELO3C002441 to be upregulated in plant leaves following PM grafting, whereas it was expressed at lower levels in stem tissues relative to leaves. This gene was expressed at significantly different levels in different tissue types. Ankyrin (ANK) repeat sequences were first detected in the context of the yeast cell cycle regulators Swi6 and $\mathrm{Cdc10}$ and the Drosophila Notch signaling protein (Breeden and Nasmyth 1987). Several plant disease resistance-related ANK proteins have been reported to date including NPR1-4 (ANK-BTB), which are key regulators of plant SAR, as well as AtPhos43 (ANK-M), which controls plant disease resistance-related signal transduction (Johal and Briggs 1992; Horvath et al. 2012). OsXB25 (ANK-M) is an important regulator of rice $x a 21$ resistance to bacterial blight, while OsPIANK1 (ANK-M) controls rice defense responses against rice blast (Schmidt et al. 2010). ACD6 and $B D A 1$ (ANK-TM) respectively regulate apoptosis and disease resistance-related signal transduction in the context of disease-related stress in plants (Kim et al. 2010; Acevedo-Garcia et al. 2014). We thus hypothesize that MELO3C002441 may play a role in resistance signaling and associated disease resistance responses. Further work, however, will be needed to clarify the functional role of this gene and to guide the development of PM-resistant melon cultivars.

The MELO3C012438 resistance gene identified in this study, which was encoded on chromosome 10, was found to be $90 \%$ homologous to the cucumber CSMLO8 gene that has previously been linked to partial PM resistance in cucumber stem, petiole, and hypocotyl tissues. CsMLO8 is a recessive resistance gene and a member of the MLO gene family identified within the region of this chromosome identified via finally-mapping. Insertion of a transposon into the transmembrane domain of the gene resulted in gene loss of function (Berg et al. 2015). The MELO3C012438 gene was found to harbor a non-synonymous SNP when comparing parental melon lines in this study. As such, our analysis was the first to identify a melon MLO gene via a forward genetics approach. Such MLO genes are widely known to govern plant biotic stress responses in other species. For example, $M d M L O$ upregulation occurs in apples in response to exposure to exogenous salicylic acid and other stimuli (Pessina et al. 2014). MLO gene expression in barley has also been found to rise following wounding or exposure to Magnaporthe grisea, paraquat, and wheat powdery mildew exposure (Han et al. 2003). Overall, the PM resistance candidate genes identified herein offer important new insights into the mechanisms governing PM resistance in melon plants and may guide the generation of resistant germplasm resources.

\section{Declarations}

\section{Author contribution statement}

FL and PG conceived and designed the study. CF developed the population. XW, LT, and YB conducted the field experiments. $\mathrm{HC}$ performed sequencing data analysis. ZD wrote the manuscript. It is worth noting that $\mathrm{HC}, \mathrm{CF}$, and ZD are co-first authors.

\section{Acknowledgments}


The financial support provided by the National Nature Science Foundation of China (No. 31672177) is gratefully acknowledged.

Conflict of interest The authors declare that they have no conflict of interest.

\section{References}

1. Acevedo-Garcia J, Kusch S, Panstruga R (2014) Magical mysterytour. MLO proteins in plant immunity and beyond. New Phytol 204:278-281. https://doi.org/10.1111/nph.12889

2. Allen GC, Flores-Vergara MA, Krasynanski S, Kumar S, Thompson WF (2006) A modified protocol for rapid DNA isolation from plant tissues using cetyltrimethylammonium bromide. Nat Protoc 1:23202325. https://doi.org/10.1038/nprot.2006.384

3. Bardin M, Carlier J, Nicot PC (1999) Genetic differentiation in the French population of Erysiphe cichoracearum, a causal agent of powdery mildew of cucurbits. Plant Pathol 48:531-540

4. Berg JA, Appiano M, Martínez MS, Hermans FW, Vriezen WH, Visser RG, Bai Y, Schouten HJ (2015) A transposable element insertion in the susceptibility gene CsaMLO8 results in hypocotyl resistance to powdery mildew in cucumber. BMC Plant Biol 15:243-256. https://doi.org/10.1186/s12870-0150635-x

5. Braun U (1995) The powdery mildews (Erysiphales) of Europe. Gustav Fischer Verlag, New York

6. Breeden L, Nasmyth K (1987) Similarity between cell-cycle genes of budding yeast and fission yeast and the Notch gene of Drosophila. Nature 329:651-659. https://doi.org/10.1038/329651a0

7. Cheng $\mathrm{H}$, Kong W, He Q, Wang X (2013) CmMLO2: A aovel gene closely associated with the powdery mildew in melon. Acta Hort Sin 40: 540-548 (in Chinese)

8. Cheng H, Kong W, Lu J, Li J (2015) Analysis of powdery mildew resistance in wild melon MLO mutant. Acta Hort Sin 42:1515-1522 (in Chinese)

9. Cheng H, Kun W, Liu D, Su Y, He Q (2012) Molecular cloning and expression analysis of CmMlo1in melon. Mol Biol Rep 39:1903-1907. https://doi.org/10.1007/s11033-011-0936-6

10. Cingolani P, Platts A, Wang LL, Coon M, Nguyen T, Wang L, Land SJ, Lu X, Ruden DM (2012) A program for annotating and predicting the effects of single nucleotide polymorphisms, SnpEff: SNPs in the genome of Drosophila melanogaster strain w1118; iso-2; iso-3. Fly (Austin) 6:80-92. https://doi.org/10.4161/fly.19695

11. Cohen Y, Eyal H, Hanania J (1990) Ultrastructure, autofluorescence, callose deposition and lignification in susceptible and resistant muskmelon leaves infected with the powdery mildew fungus Sphaerothecafuliginea. Physiol Mol Plant P 36:191-204. https://doi.org/10.1016/08855765(90)90025-S

12. Cui H, Ding Z, Fan C, Zhu Z, Zhang H, Gao P, Luan F (2020) Genetic mapping and nucleotide diversity of two powdery mildew resistance loci in melon (Cucumis melo). Phytopathology 110:19701979.https://doi.org/10.1094/PHYTO-03-20-0078-R 
13. Cui H, Zhu Q, Zhu Z, Fan C, Gao P, Yan C, Luan F, Zhang Q (2018) Advance on powdery mildew and molecular genetic base of resistance in melon. ZhongguoGua-cai 31:1-7.

https://doi.org/10.16861/j.cnki.zggc.2018.0037 (in Chinese)

14. de Oliveira Rabelo H, de Silva Santos L, Diniz GMM, Marin MV, Braz LT, McCreight JD (2017) Cucurbits powdery mildew race identity andreaction of melon genotypes. PesquiAgropecu Trop 47:440-447. https://doi.org/10.1590/1983-40632017v4749537

15. Dogimont C (2011) Gene list 2011 for melon. Cucurbit Genetics Cooperative Report 33-34:104-133

16. Epinat C, Pitrat M, Bertrand F (1992) Genetic analysis of resistance of five melon lines to powdery mildews. Euphytica 65:135-144. https://doi.org/10.1007/BF00022575

17. Fazza AC, Dallagnol LJ, Fazza AC, Monteiro CC, de Lima BM, Wassano DT, Camargo LEA (2013) Mapping of resistance genes to races 1, 3 and 5 of Podosphaeraxanthiinn melon PI 414723. Crop Breed Appl Biotechnol 13:349-355. http://dx.doi.org/10.1590/S1984-70332013000400005

18. Fukino N, Ohara T, Monforte AJ, Sugiyama M, Sakata Y, Kunihisa M, Matsumoto S (2008) Identification of QTLs for resistance to powdery mildew and SSR markers diagnostic for powdery mildew resistance genes in melon (Cucumis meloL.). Theor App Genet 118:165-175. https://doi.org/10.1007/s00122-008-0885-1

19. Garcia-Mas J, Benjak A, Sanseverino W, Bourgeois M, Mir G, González V M, Hénaff E, Câmara F, Cozzuto L, Lowy E, Alioto T, Capella-Gutiérrez S, Blanca J, Cañizares J, Ziarsolo P, Gonzalez-lbeas D, Rodríguez-Moreno L, Droege M, Du L, Alvarez-Tejado M, Lorente-Galdos B, Melé M, Yang L, Weng Y, Navarro A, Marques-Bonet T, Aranda M A, Nuez F, Picó B, Gabaldón T, Roma G, Guigó R, Casacuberta $\mathrm{J}$ M, Arús P, Puigdomènech P (2012) The genome of melon (Cucumis melo L.). P Natl Acad Sci USA. 109 (29):11872- 11877. https://doi.org/10.1073/pnas.1205415109

20. Han D, Li Z, Cao L, Chen Y (2003) Advances in Mlogene resistant to powdery mildew in barley. Acta Bot Boreal-Occid Sin 23:496-502.

21. Harwood RR, Markarian D (1968a) A genetic survey of resistance to powdery mildew in muskmelon. J Hered 23:213-217

22. Harwood RR, Markarian D (1968b) The inheritance of resistance to powdery mildew in the cantaloupe variety seminole. J Hered 11:126-130

23. Horvath DM, Stall RE, Jones JB, Pauly MH, ValladGE, Dahlbeck D, StaskawiczBJ, Scott JW (2012) Transgenic resistance confers effective field level control of bacterial spot disease in tomato. Plos One 7:e42036.https://doi.org/10.1371/journal.pone.0042036

24. Hosoya K, Kuzuya M, Murakami T, Kato K, Narisawa K, Ezura H (2000) Impact of resistant melon cultivars on Sphaerothecafuliginea. Plant Breed 119:286-288. https://doi.org/10.1046/j.14390523.2000.00489.x

25. Hosoya K, Narisawa K, Pitrat M, Ezura H (1999) Race identification in powdery mildew (Sphaerothecafuliginea) on melon (Cucumis melo) in Japan. Plant Breed 118:259-262. https://doi.org/10.1046/j.1439-0523.1999.118003259.x 
26. Humphry M, Consonni C, Panstruga R (2006) mlo-based powdery mildew immunity: silver bullet or simply non-host resistance. Mol Plant Pathol 7(6):605-610. https://doi.org/10.1111/j.13643703.2006.00362.x

27. Humphry M, Bednarek P, Kemmerling, Koh S, Stein M, Gobel U, Stu“ber K, Pislewska-Bednarek M, Loraine A, Schulze-Lefert P (2010) A regulon conserved in monocot and dicot plants defines a functional module in antifungal plant immunity. P Natl Acad Sci USA 107(50):21896-21901. https://doi.org/10.1073/pnas.1003619107

28. Iovieno P, Andolfo G, Schiavulli A, Catalano D, Ricciardi L, Frusciante L, Ercolano MR, Pavan S (2015) Structure, evolution and functional inference on the Mildew Locus O (MLO) gene family in three cultivated Cucurbitaceae spp.. BMC Genomics 16:1112. https://doi.org/10.1186/s12864-015-2325-3

29. Jagger IC, Whitaker TW, Porter DR (1938) Inheritance in Cucumis melo of resistance to powdery mildew (Erysiphe cichoracearum). Phytopathology 28:761-773

30. Johal GS, Briggs SP (1992) Reductase activity encoded by the HM1 disease resistance gene in maize. Science 258:985-987. https://doi.org/10.1126/science.1359642

31. Kenigsbuch D (1989) Independent inheritance of resistance to race 1 and race 2 of Sphaerothecafuliginea in Muskmelon. Plant Dis 73:206-208

32. Kim JY, Kim WY, Kwak KJ, Oh SH, Han YS, Kang H (2010) Glycine-rich RNA-binding proteins are functionally conserved in Arabidopsis thaliana and Oryza sativa during cold adaptation process. $J$ Exp Bot 61:2317-2325. https://doi.org/10.1093/jxb/erq058

33. Kř́stková E, Lebeda A, Sedláková B (2007) Temporal and spatial dynamics of powdery mildew species on cucurbits in the Czech Republic. In: ISHS Acta Horticulturae 731: III International Symposium on Cucurbits, pp. 337-343. https://doi.org/10.17660/ActaHortic.2007.731.45

34. Kř́stková E, Lebeda A, Sedláková B (2009) Species spectra, distribution and host range of cucurbit powdery mildews in the Czech Republic, and in some other European and middle eastern countries. Phytoparasitica 37:337-350. https://doi.org/10.1007/s12600-009-0045-4.

35. Kourelis J, van der Hoorn R A L (2018) Defended to the nines: 25 years of resistance gene cloning identifies nine mechanisms for R protein function. Plant Cell 102(12):178-193. https://doi.org/10.1105/tpc.17.00579

36. Kim H, O'Connell R, Maekawa-Yoshikawa M, Uemura T, Neumann U, Schulze-Lefert P (2014) The powdery mildew resistance protein RPW8.2 is carried on VAMP721/722 vesicles to the extra haustorial membrane of haustorial complexes. Plant J 79(5):83547.https://doi.org/10.1111/tpj.12591

37. Li B, Zhao Y, Zhu Q, Zhang Z, Fan C, Amanullah S, Gao P, Luan F (2017) Mapping of powdery mildew resistance genes in melon (Cucumis meloL.) by bulked segregant analysis. Sci Hort 220:160-167. https://doi.org/10.1016/j.scienta.2017.04.001

38. Li H, Handsaker B, Wysoker A, Fennell T, Ruan J, Homer N, Marth G, Abecasis G, Durbin R (2009) The sequence alignment/map format and SAMtools. Bioinformatics 25:2078-2079. https://doi.org/10.1093/bioinformatics/btp352 
39. Livak KJ, Schmittgen TD (2001) Analysis of relative gene expression data using real-time quantitative PCR and the 2(-Delta Delta C(T)) method. Methods 25: 2-8.

40. Ma H, Wei Z, Zu Y, Luan F (2011) Physiological races identification of powdery mildew on main cucurbits in Heilongjiang Province during 2009-2010. J Plant Protection 3:284-288

41. McCreight JD (2006) Melon-powdery mildew interactions reveal variation in melon cultigens and Podosphaeraxanthii races 1 and 2. J Am Soc Hort Sci 131:59-65.

https://doi.org/10.21273/JASHS.131.1.59

42. McCreight JD, Coffet MD (2011) Inheritance of resistance in melon PI 313970 to cucurbit powdery mildew incited by Podosphaeraxanthii Race S. HortScience46:838-840.

https://doi.org/10.21273/HORTSCI.46.6.838

43. McCreight JD, Pitrat M, Thomas CE, Kishaba AN, Bohn GW (1987) Powdery mildew resistance genes in muskmelon. J Am Soc Hort Sci 112:156-160.

44. Meng L, Li H, Zhang L, Wang J (2015) QTL IciMapping: integrated software for genetic linkage map construction and quantitative trait locus mapping in biparental populations. Crop J3:269-283. https://doi.org/10.1016/j.cj.2015.01.001

45. Ning X, Wang X, Gao X, Zhang Z, Zhang L, Yan W, Li G (2014) Inheritances and location of powdery mildew resistance gene in melon Edisto47. Euphytica 195(3):345-

353.https://doi.org/10.1007/s10681-013-1000-5

46. Orgil U, Araki H, Tangchaiburana S, Berkey R, Xiao S (2007) Intraspecific Genetic Variations, Fitness Cost and Benefit of RPW8, A Disease Resistance Locus in Arabidopsis thaliana. Genetics 176(4):2317-2333. https://doi.org/10.1534/genetics.107.070565

47. Perchepied L, Bardin M, Dogimont C, Pitrat M (2005) Relationship between loci conferring downy mildew and powdery mildew resistance in melon assessed by quantitative trait loci mapping. Phytopathology 95:556-565. https://doi.org/10.1094/PHYTO-95-0556

48. Périn C, Hagen L, De Conto V, Katzir N, Danin-Poleg Y, Portnoy V, Baudracco-Arnas S, Chadoeuf J, Dogimont C, Pitrat M (2002) A reference map of Cucumis melobased on two recombinant inbred line populations. Theor Appl Genet 104:1017-1034. https://doi.org/10.1007/s00122-002-0864-x

49. Pessina S, Pavan S, Catalano D, Gallotta A, Visser RG, Bai Y, Malnoy M, Schouten HJ (2014) Characterization of the MLO gene family in Rosaceae and gene expression analysis in Malus domestica. BMC Genomics 15:618. https://doi.org/10.1186/1471-2164-15-618

50. Pitrat M (1991) Linkage groups in Cucumis melo L. J Hered 82:406-411. https://doi.org/10.1093/oxfordjournals.jhered.a111112

51. Rio DC, Ares M, Hannon GJ, Nilsen TW (2010) Purification of RNA using TRIzol (TRI Reagent). Cold Spring HarbProtoc 2010:1-3. https://doi.org/10.1101/pdb.prot5439

52. Román B, Gómez P, Picó B, López C, Janssen D (2019) Candidate gene analysis of tomato leaf curl New Delhi virus resistance in, Cucumis melo. Sci Hort 243:12-20. https://doi.org/10.1016/j.scienta.2018.07.005 
53. Schmidt F, Marnef A, Cheung MK, Wilson I, Hancock J, Staiger D, Ladomery M (2010) A proteomic analysis of oligo (dT)-bound mRNA containing oxidative stress-induced Arabidopsis thaliana RNAbinding proteins ATGRP7 and ATGRP8. Mol Biol Rep 37:839-845. https://doi.org/10.1007/s11033009-9636-x

54. Takagi H, Abe A, Yoshida K, Kosugi S, Natsume S, Mitsuoka C, Uemura A, Utsushi H, Tamiru M, Takuno S, Innan H, Cano LM, Kamoun S, Terauchi R (2013) QTL-seq: rapid mapping of quantitative trait loci in rice by whole genome resequencing of DNA from two bulked populations. Plant J 74: 174183. http://dx.doi.org/10.1111/tpj.12105.

55. Teixeira AP, da Silva Barreto FA, Camargo LEA (2008) An AFLP marker linked to the $P m-1$ gene that confers resistance to Podosphaeraxanthiirace 1 in Cucumis melo. Genet Mol Biol 31:547-550. http://dx.doi.org/10.1590/S1415-47572008000300023

56. Wang X, Li G, Gao X, Xiong L, Wang W, Han R (2011) Powderymildew resistance gene (Pm-AM) located in a segregation distortion regionof melon LGV. Euphytica 180:421-428. https://doi.org/10.1007/s10681-011-0406-1

57. Yuste-Lisbona FJ, Capel C, Sarria E, Torreblanca R, Gómez-Guillamón ML, Capel J, Lozano R, LópezSesé Al (2011) Genetic linkage map of melon (Cucumis meloL.) and localization of a major QTL for powdery mildew resistance. Mol Breed 27:181-192. https://doi.org/10.1007/s11032-010-9421-5

58. Zhang C, Ren Y, Guo S, Zhang H, Gong G, Du Y, Xu Y (2012) Application of comparative genomics in developing markers tightly linked to the $P m-2 F$ gene for powdery mildew resistance in melon (Cucumis meloL.). Euphytica 190:157-168. https://doi.org/10.1007/s10681-012-0828-4

59. Zheng Y, Xu F, Li Q, Wang G, Liu N, Gong Y, Li L, Chen ZH, Xu S (2018) QTL mapping combined with bulked segregant analysis identify SNP markers linked to leaf shape traits in Pisum sativum using SLAF sequencing. Front Genet 9:615. https://doi.org/10.3389/fgene.2018.00615

\section{Figures}




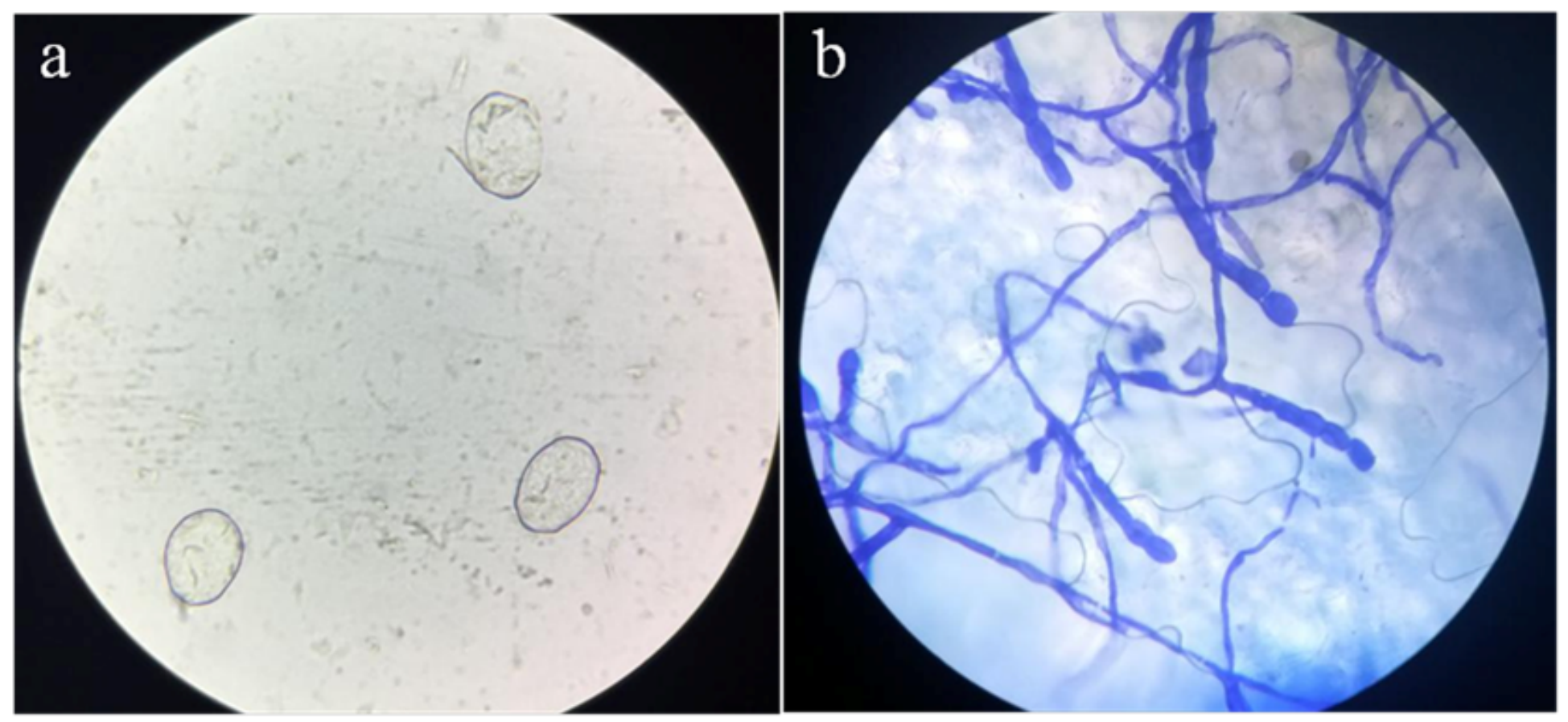

Figure 1

Representative spores isolated from melon leaves and colonies on melon leaves a: The spores isolated from melon leaves $(10 \times 40$, Optical microscope) b: Colonies on melon leaves stained with Coomassie brilliant blue $(10 \times 25$, Optical microscope $)$. 

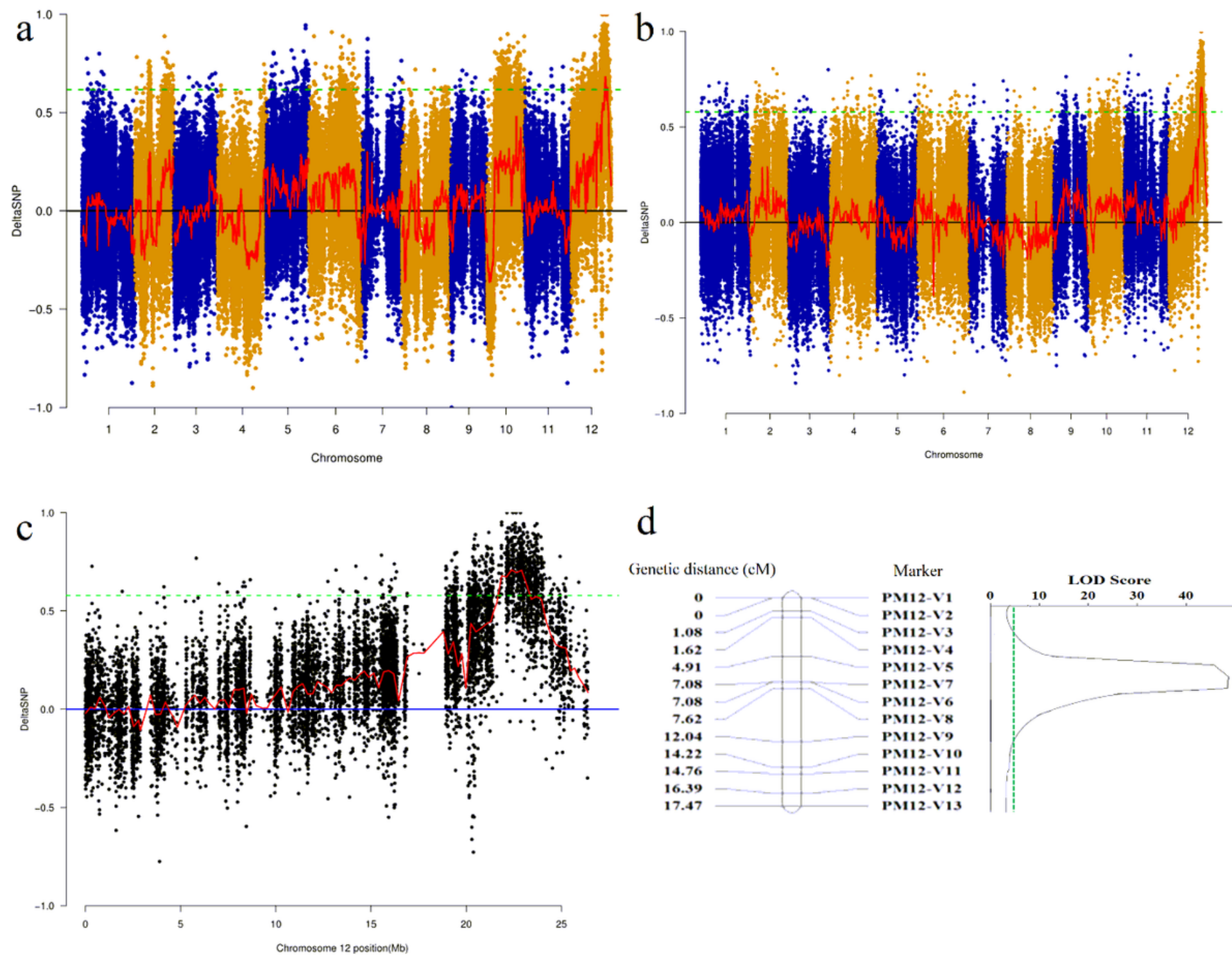

d

Genetic distance (cM)

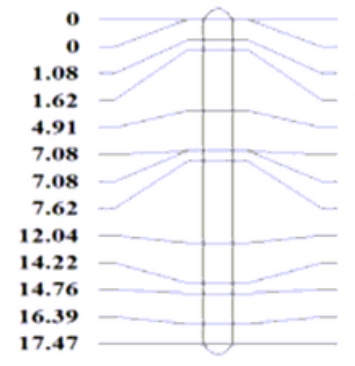

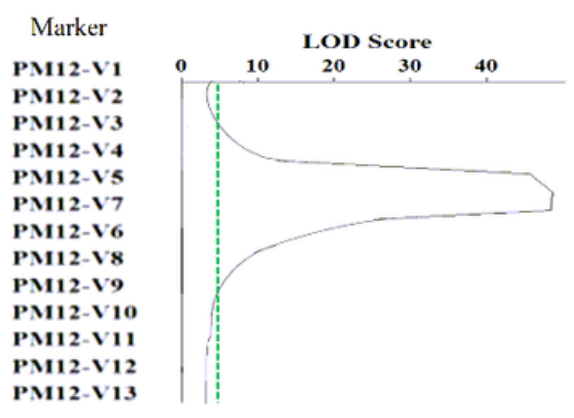

Figure 2

(a) The results of $\triangle$ SNP-index value comparisons for the LRSR-pool and the LSSS-pool. (b) The $\triangle S N P$ index results when comparing the LRSS-pool and the LSSS-pool. (c) Preliminary mapping of dominant disease resistance genes on chromosome 12 in melon. (d) Verification of BSA localization results on chromosome 12. Note: The X-axis indicates the position on melonchromosome 12, and the $Y$-axis indicates $\triangle S N P$-index values. The dotted green line is the threshold under the $95 \%$ confidence interval. 

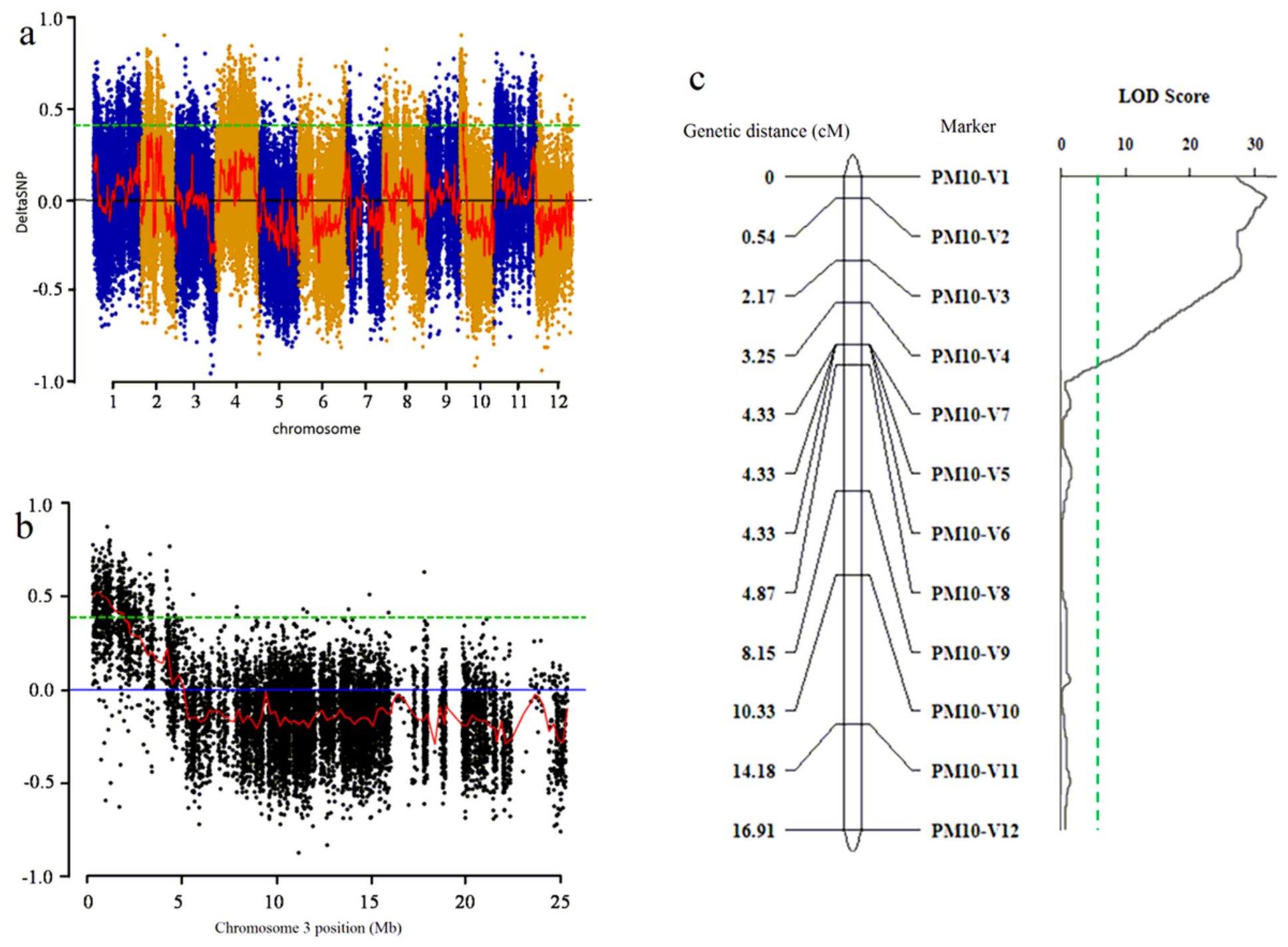

Figure 3

(a) $\triangle$ SNP-index results for the LRSR-pool and the LRSS-pool. (b) Preliminary mapping of recessive disease resistance genes onmelonchromosome 10. (c) Verification of BSA localization results on chromosome 10. Note: The X-axis indicates the position on chromosome 10 in melon, and the $\mathrm{Y}$-axis indicates $\triangle S N P$-index values. The dotted green line is the threshold under the $95 \%$ confidence interval. 

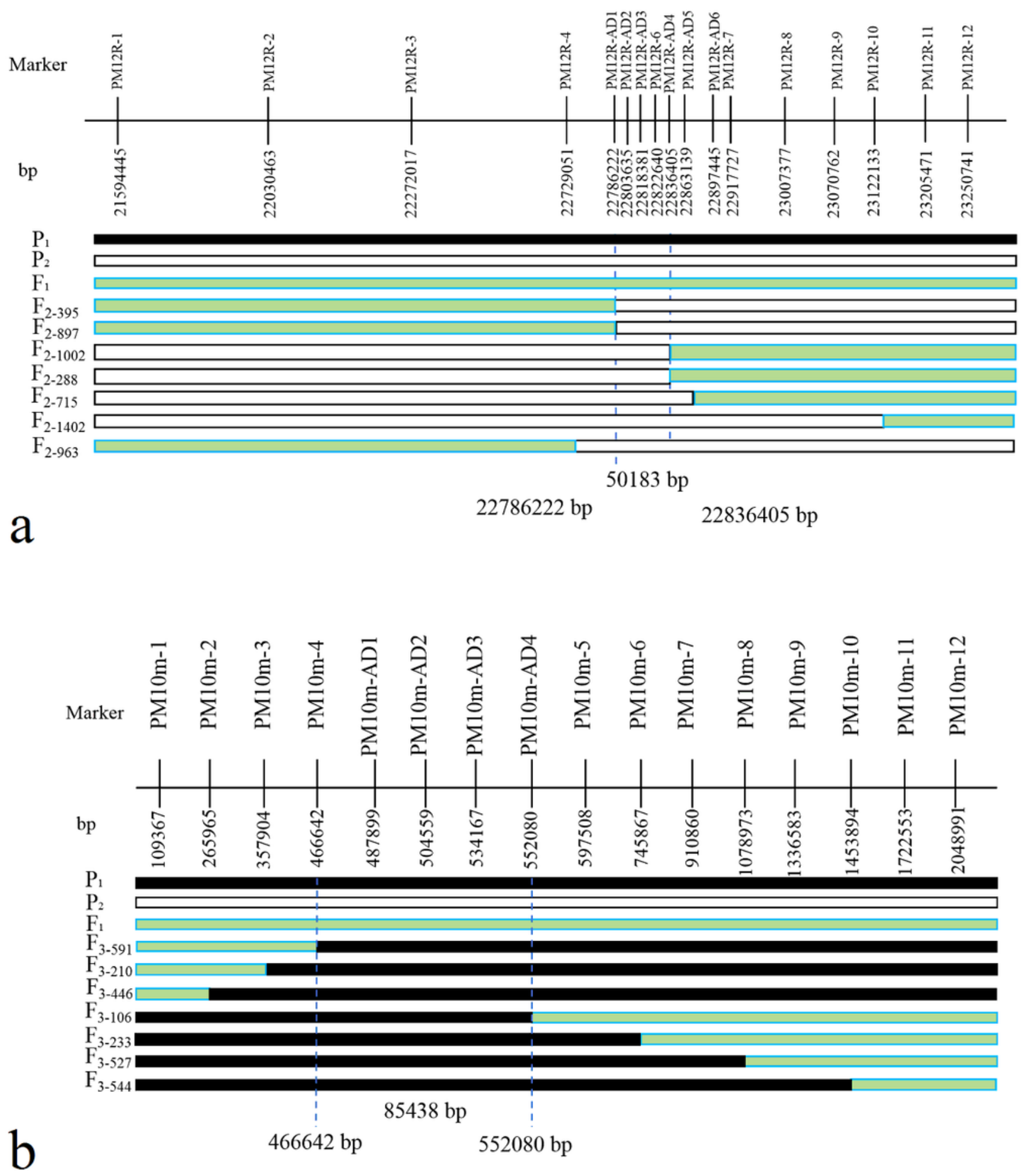

Figure 4

(a) Finally-mapping results forCmPMRI. (b) Finally-mapping resultsforCmPMrs. 

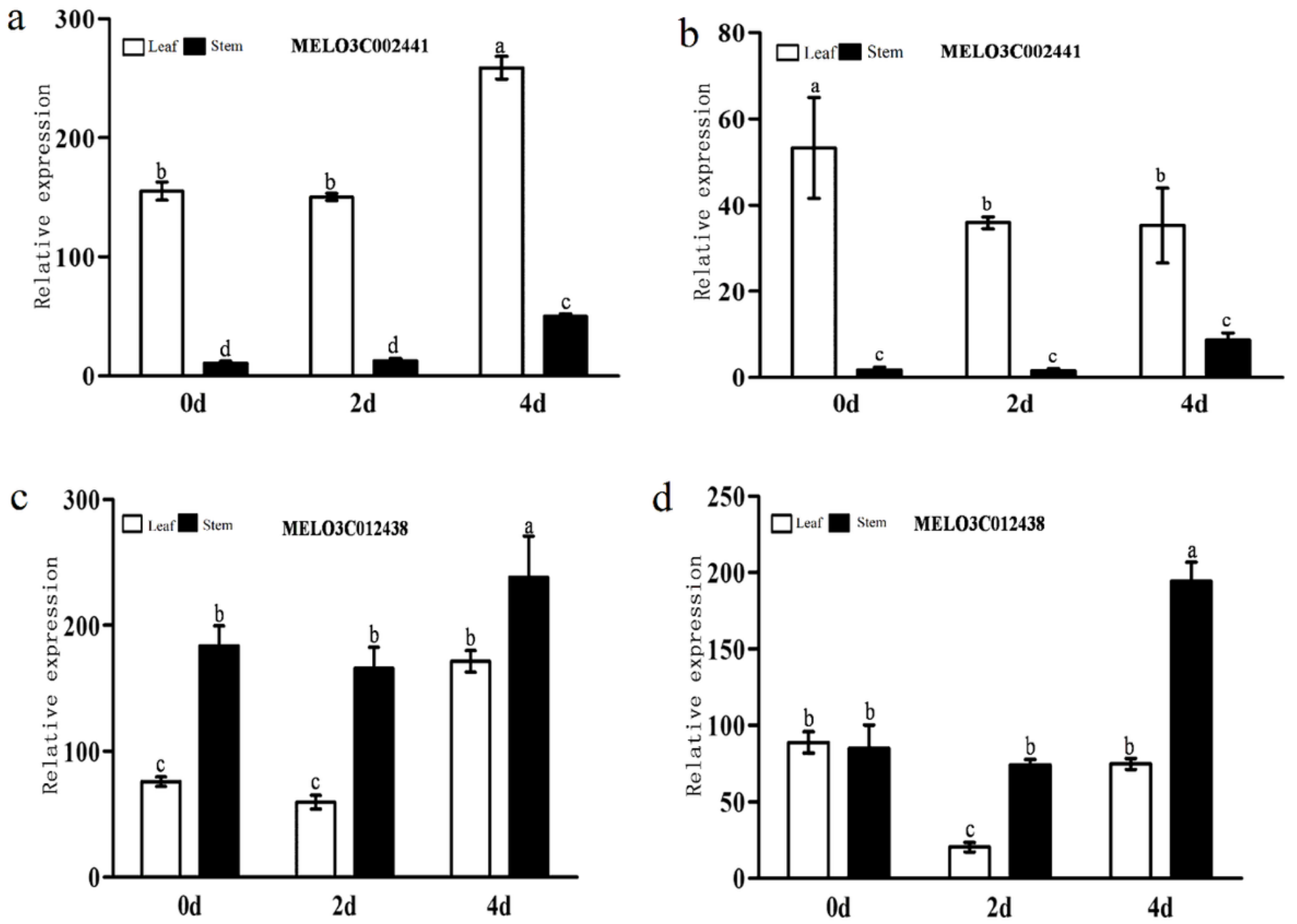

Figure 5

Relative MEL03C002441 expression in leaves and stems a: MR-1 c: M4-7. Relative MEL03C012438 expression in leaves and stems b: MR-1 d: M4-7.Identical letters on bars indicate a lack of any significant difference in expression between these bars, while different letters indicate significant differences in expression. 


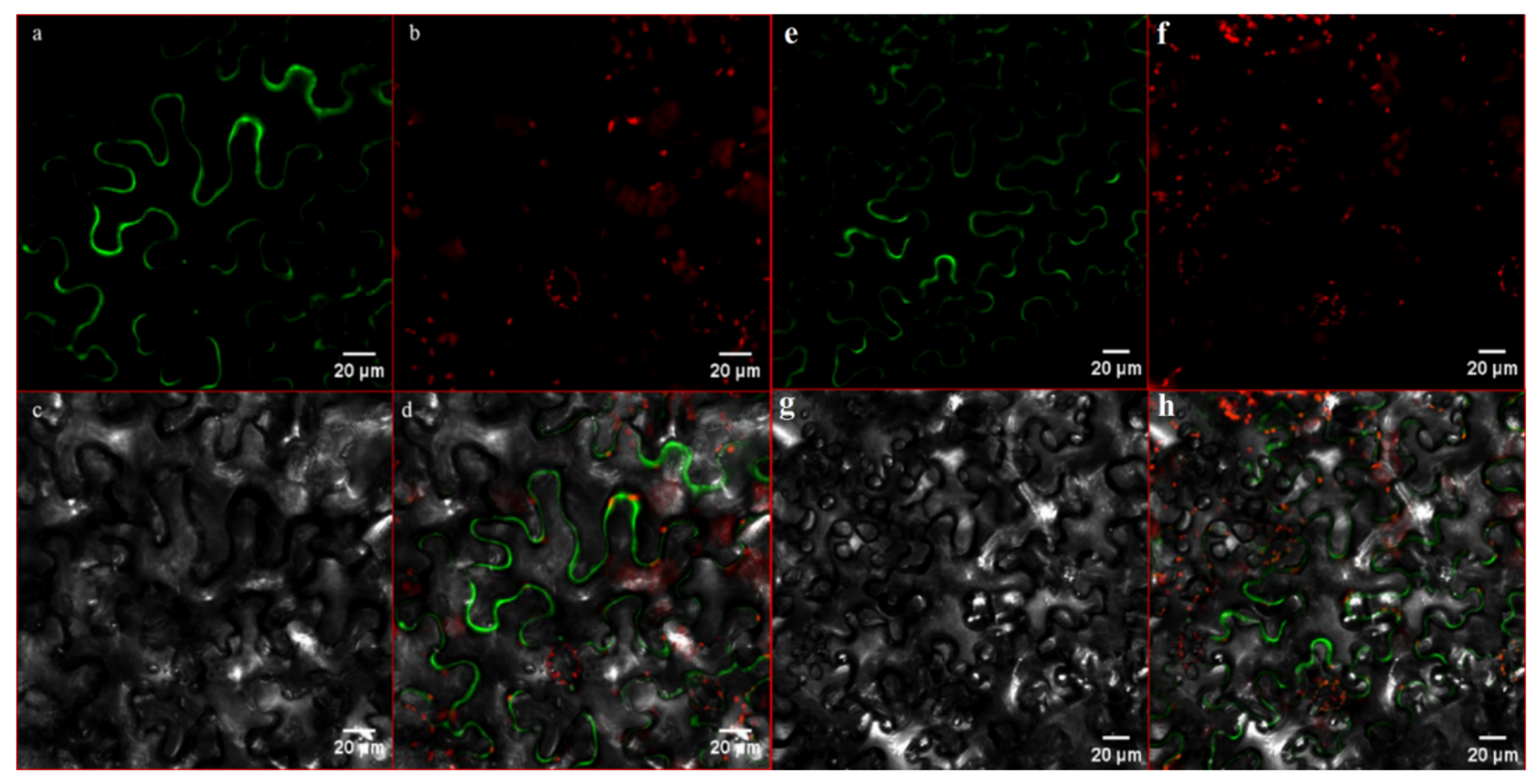

\section{Figure 6}

MELO3C002441 subcellular localization. a. MELO3C002441-GFP fluorescent signal. b. Chloroplast fluorescent signal. c. No FITC excitation. d. MELO3C002441-GFP and chloroplast merged image. MELO3C012438 subcellular localization. e. MEL03C012438- GFP fluorescent signal. f. Chloroplast fluorescent signal. g. No FITC excitation. h. MELO3C012438-GFP and chloroplast merged image.

\section{Supplementary Files}

This is a list of supplementary files associated with this preprint. Click to download.

- SupplementaryFigure.docx

- SupplementaryTable.docx 